\title{
Simulation Modeling of Cost Overrun in Construction Project in Ethiopia \\ Geletaw Taye
}

\begin{abstract}
Cost is an essential part of any construction project. It was observed that cost overrun is one of the most frequently occurring issues in construction projects of Ethiopia and it is more severe in different parts of the country. The aim of this research has identified the factors that influence cost overruns of construction projects, quantified the percentage of identified factors, established probability distribution of identified factors and develop simulation modeling of cost overrun. The study was conducted based on the desk study and questionnaire survey. Questionnaire surveys were analyzed by using Relative Important Index (RII) ranking and significance of data checked by using a t-test at a 95\% confidence level. Based on the desk study of 19 projects, a simulation model of cost overrun was developed by using the Monte Carlo simulation method. Simulation models showed a higher frequency of cost overrun occurring up to 10\%. This indicates that the actual cost of most construction projects runs up to $10 \%$ over the budgeted cost of work performed.

Authors Keywords; - cost overrun, Monte Carlo simulation modeling, probability distribution
\end{abstract}

\section{INTRODUCTION}

Cost is the essential part for any construction project.in recent report (Shanmugapriya \& Subramanian, 2013) it has been shown Cost overruns involves unanticipated costs incurred more than the budgeted amounts. And also in another recent report (Saidu \& Shakantu, 2016) it has been shown cost overrun as simply an occurrence, where the final or actual cost of a project surpasses the original or initial estimates. (Ubani et al., 2011) outlined that Cost Overruns have also been referred to as the percentage of actual or final costs above the estimated or tender cost of a project. Nega (2008) says that cost overrun as an occurrence, in which the delivery of contracted goods/services is claimed to require more financial resources than was originally agreed upon between a project sponsor and a contractor. (Kaming et al., 1997) outlined that the factors influencing construction cost overrun on high- rise projects in Indonesia, they found that cost overruns occur more frequently and are thus a more severe problem than time overruns on high-rise construction in Indonesia. The predominant factors influencing cost overruns are material cost increases due to inflation, inaccurate materials estimating and degree of project complexity. (Kaming, 1997, Morris et al., 1990) outlined that four factors were identified from the existing research findings. These are; design changes, inadequate planning, unpredictable weather conditions; and fluctuations in the cost of building materials. In a recent report (Stukhart and George, 1997) it has been shown cost overrun is one of the most frequently occurring issues in construction projects

\footnotetext{
Revised Manuscript Received on November 15, 2019

Geletaw Taye, Lecturer, Dilla University, Department of Construction technology and management, Dilla University ,Dilla, Ethiopia,
}

worldwide and it is more severe in developing countries. Like many other developing countries, the construction industry in Ethiopia also affected by the cost overrun. Most of the construction projects in Ethiopia are exposed to cost overrun this leading to loss of projects profit, budget shortfall of project owners, falling the project to deliver on time, the company or firms exposed to bad debt or bankruptcy, and it also considered another a big problem, which hinders project's progress since it decreases the contractor profit leading to huge losses leaving the project in a big trouble.

\section{OBJECTIVE OF RESEARCH}

The study in this research aimed to identify and analyze construction cost overrun in the Ethiopia construction industry. The specific objectives are as follows:

- To identify the influencing factors of cost overrun in construction projects.

- To quantify the percentage of influencing factors of cost overrun in the construction project.

- To establish the probability distribution of identifying influencing factors of cost overrun in the construction projects.

- To develop a simulation model of cost overrun

\section{LITERATURE REVIEW}

\section{A. Concepts of Cost overrun}

in a recent report (Windapo \& Cattell, 2013)it has been shown the concept of cost overrun is a term for a cost increment, or higher spending includes unexpected expenses over a given budget plan for a period. Cost overrun as the adjustment in contract sum partitioned by the first contract grant sum. Be that as it may, cost invades characterized as an overabundance of genuine cost over spending plan. Cost overrun is additionally now and then called cost acceleration, cost increment or spending invades.

\section{B. Cost overruns worldwide}

(Memon, 2013) out lined that the history of the construction industry worldwide abounds in projects that were completed with a significant amount of cost overrun, despite the use of modern technologies and software packages. In the recent report (Brunes \& Lind, 2014) it has been shown Cost overruns were slightly lower in Europe compared to North America and other geographical areas. In Canada, (Odeck, 2014) outlined that 50 road construction projects were investigated, and the results revealed a cost overrun of up to $82 \%$ in 2006 . 


\section{Simulation Modeling of Cost Overrun in Construction Project in Ethiopia}

\section{C, Cause of cost overrun in the construction project}

In India, (Subramani, et al., 2014) outlined that the major causes of cost overruns are slow decision-making at the planning stage of a project; poor project schedules and management; increases in the prices of materials and machines; poor contract management; poor design/delay in producing design; rework due to mistakes or wrong work; land-acquisition problems; poor estimation or estimation techniques, and the long-time taken between the design and the time of bidding/tendering.In Egypt, Aziz (2013) outlined that causing cost overruns in waste-water projects and concluded that the major causes of cost overruns are lowest tendering procurement method; additional works that are not included in the original work; bureaucracy in tendering or offering methods; wrong cost-estimation methods, and funding problems by the client.

\section{METHODOLOGY}

\section{A. Study Design}

This research was conducted using the quantitative approach and was carried out in four stages. The stages involved in the review of literature, data collection, data analysis, and conclusion.

B. Study Variables

Dependent Variable: - cost overrun in construction. Independent Variable: -cost overrun factors; - client factor, contractor factor, consultant factor, project-related factor, and other factors.

C. Population

For this study, the target populations were construction companies, consultants and public and private clients.

D. Sampling Techniques and Sampling Size Determination Systematic random sampling techniques used for this research. Sample members from the population were selected according to a random starting point and a fixed periodic interval. The interval was calculated by dividing the population size by the desired sample size.

\section{E. Method of data collection}

The data gathered approach for the research used both primary and secondary data collection methods. The primary data was collected through questionnaires, interviews and contract document analysis of ongoing construction and secondary data was collected from record data document of previously completed projects. For this study, 96 questionnaires were distributed for three company i.e. client, contractor, and consultant. 16, 60 and 20 questionnaires were distributed for a client, contractor, and consultant respectively. From this distributed questionnaire $81.25 \%$ (13 out of 16) returned from the client, $86.66 \%$ (52 out of 60 ) returned from the contractor and $80 \%$ (16 out of 20) returned from the Consultant. Totally $84.37 \%$ (81 out of 96) returned from three Companies. The data analyzed by relative important index.

\section{FINDING}

\section{A. Factor of cost overrun}

The factor that influencing construction cost overrun from the questionnaire survey was identified based on respondents' responses on each variable of cost overrun factor. The fluctuation of construction material cost was the 1st ranked factor of cost overrun with an RII value of 0.7827 . Inadequate project planning and scheduling were the $2^{\text {nd }}$ ranked factor of cost overrun. the top and fatal consequences of inadequate project planning and scheduling in construction project was project failure and also caused for the redundant task this increase the cost and extension of time to complete the project. Poor economic conditions were ranked as the 3rd factor of cost overrun. Poor site management was ranked at $4^{\text {th }}$ level, it also causes of poor productivity of labor due to workers were standing around and waiting, and poor coordination of workers \& subcontractors and workers were not properly skilled.

\section{Table 1 Factor of Cost Overrun (source: compiled by author)}

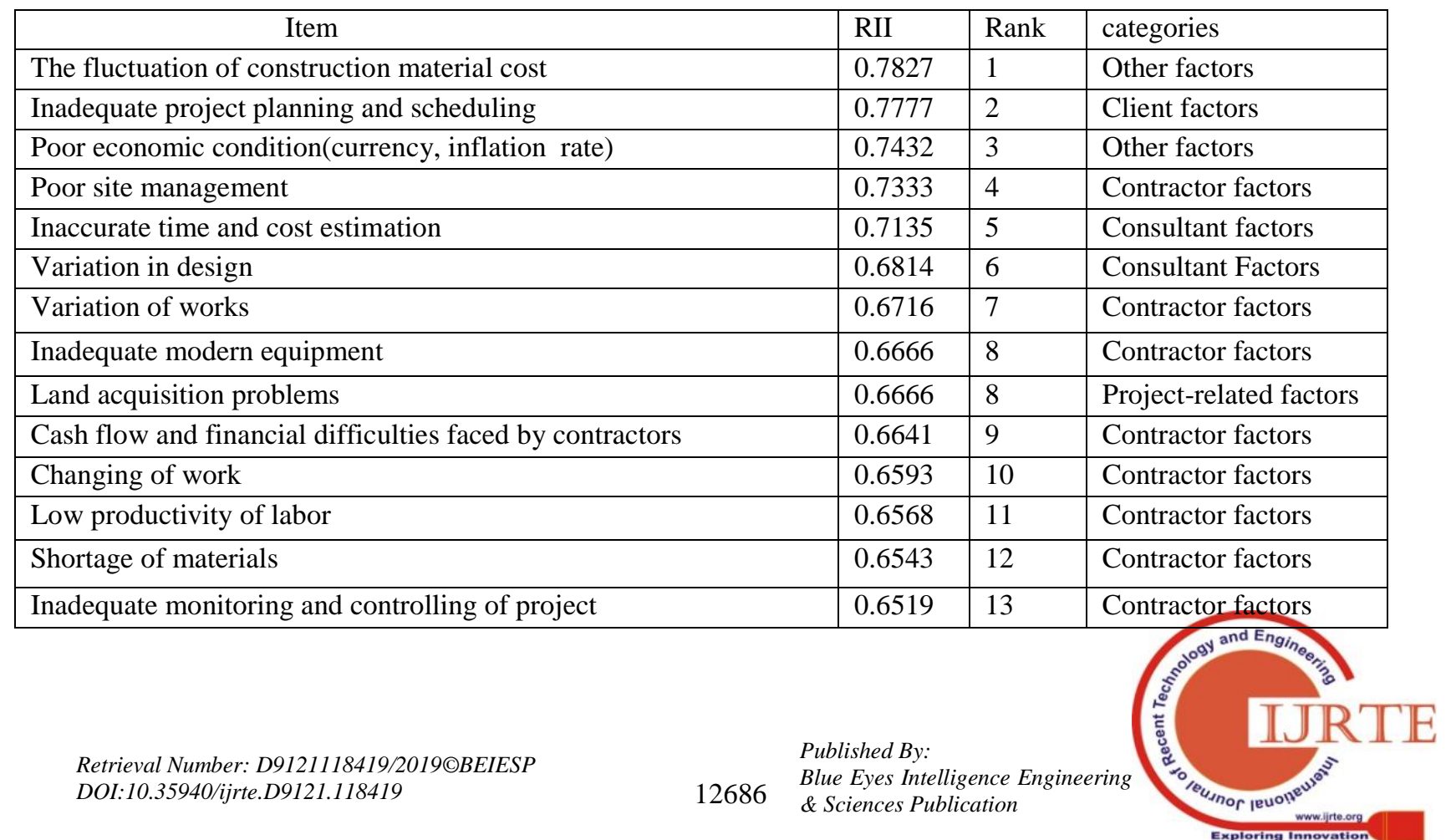




\begin{tabular}{|l|l|l|l|}
\hline Frequent design change & 0.6494 & 14 & Consultant factors \\
\hline Unsuitable construction method & 0.6444 & 15 & Contractor factors \\
\hline Inaccurate site investigation & 0.642 & 16 & Consultant factors \\
\hline Long wait time for testing sample approval & 0.6296 & 17 & Consultant factors \\
\hline Corruption & 0.6272 & 18 & Other factors \\
\hline Long waiting time for approval of drawing & 0.6222 & 19 & Consultant factors \\
\hline Shortage of skilled labor & 0.6198 & 20 & Contractor factors \\
\hline Poor estimation techniques & 0.6148 & 21 & Consultant factors \\
\hline Additional work & 0.6128 & 22 & Contractor factor \\
\hline Rework & 0.6025 & 23 & Contractor factor \\
\hline Lack/inadequate experience of a consultant & 0.5778 & 24 & Consultant factor \\
\hline Contractual procedure and type of contract & 0.5728 & 25 & Other factors \\
\hline Increasing tax & 0.5556 & 26 & Other factors \\
\hline A contractual claim & 0.5457 & 27 & Other factors \\
\hline Slow information between parties & 0.5259 & 28 & Other factors \\
\hline Managerial incompetence of client & 0.4963 & 29 & Client factors \\
\hline Financial difficulties faced by owners & 0.4864 & 30 & Client factors \\
\hline Change in scope of the project & 0.484 & 31 & Client factors \\
\hline The poor relationship between labor and management & 0.4741 & 32 & Other factors \\
\hline The complexity of contract size and change size of the project & 0.4568 & 33 & Project-related factors \\
\hline Dispute on site & 0.442 & 34 & Other factors \\
\hline
\end{tabular}

\section{B. Percentage of identified factors}

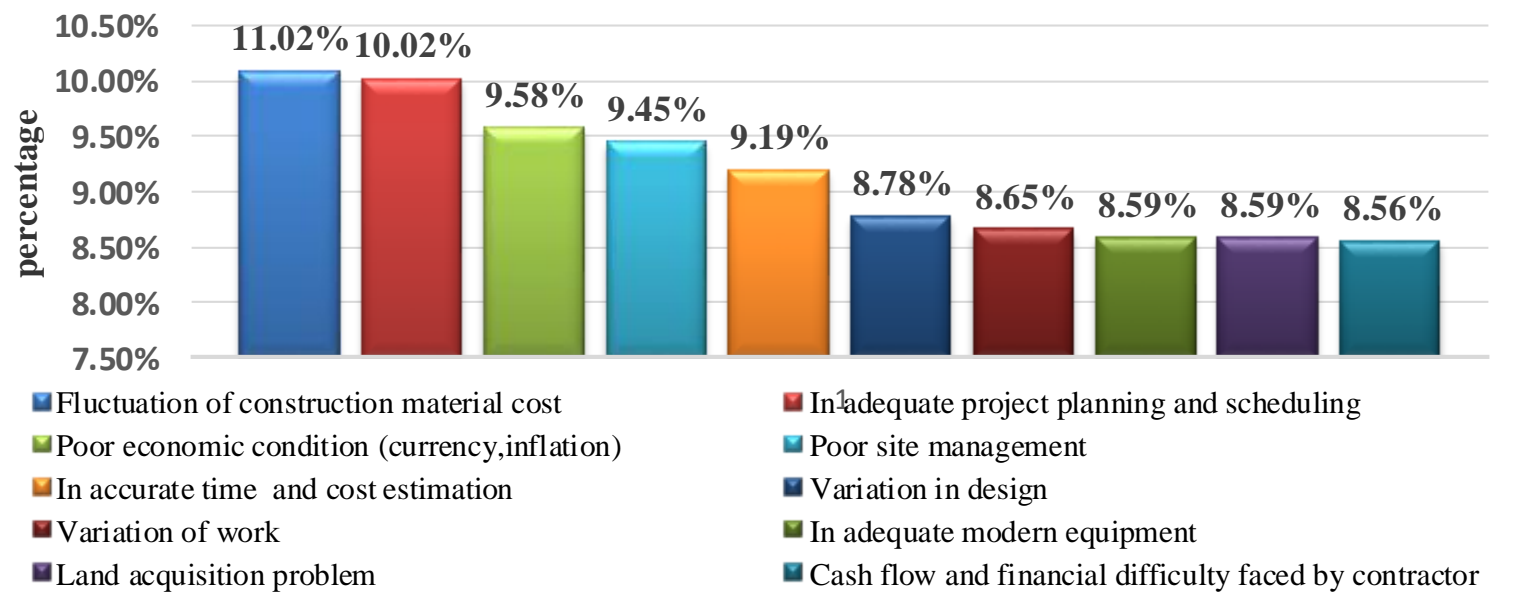

Fig 1 Percentage of top ten factors of cost overrun (source; compiled by author)

\section{C. probability distribution of identified factors}

The probability distribution was expressed by using normal probability distribution. (Gordon, 2010) Outlined that the value of the mean fixes the location of the normal curve, where it is centered. In all probability curves, half the scores lie to the left of the mean and half to the right. The value of the standard deviation determines the spread; the higher the standard deviation, the more flat of the curve. In fig 3 and fig 4 according to Gordon says that "scores are most crowded in intervals around the mean and the curve is highest" this tells us the two factors are more significant than others. Towards the ends of the curve, the height is decreased; the scores become less dense from the mean we go. This tells us that observations around the mean are more

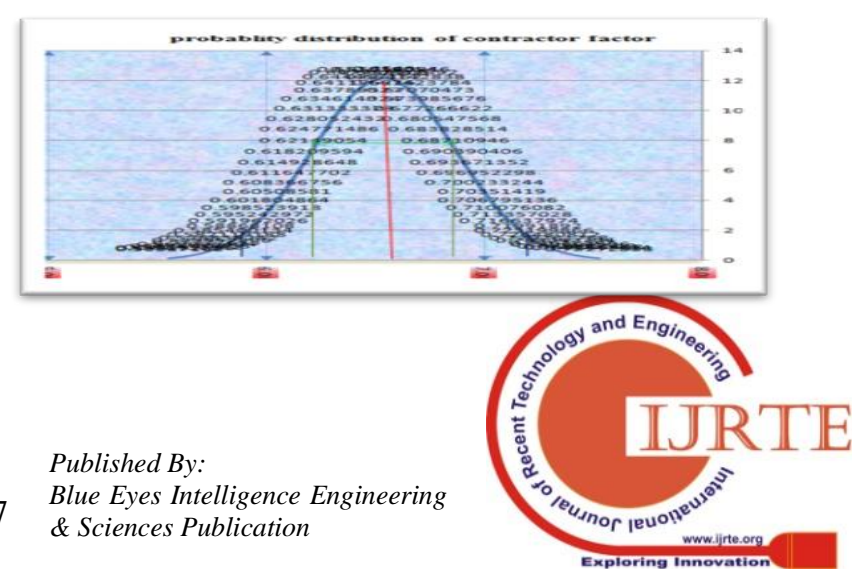




\section{Simulation Modeling of Cost Overrun in Construction Project in Ethiopia}

likely to occur than observations further from the center.
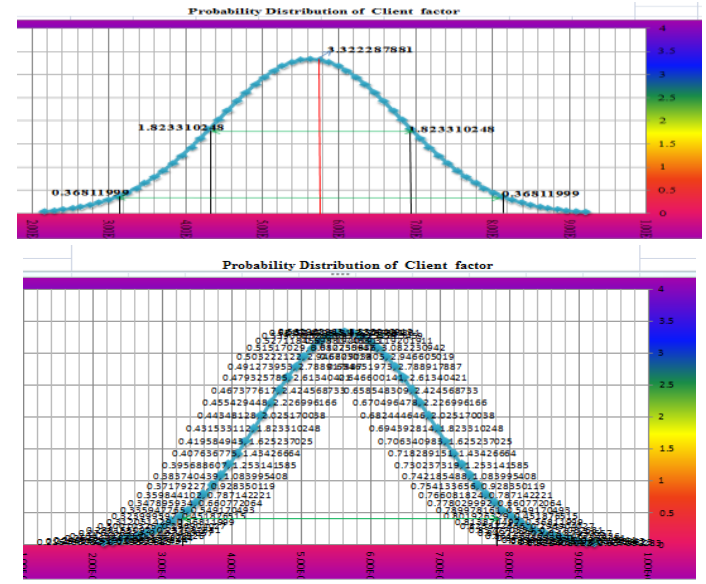

Fig 2 Probability Distribution of Client Factor (mean; 0.5629, standard deviation; 0.119) (source; compiled by author)

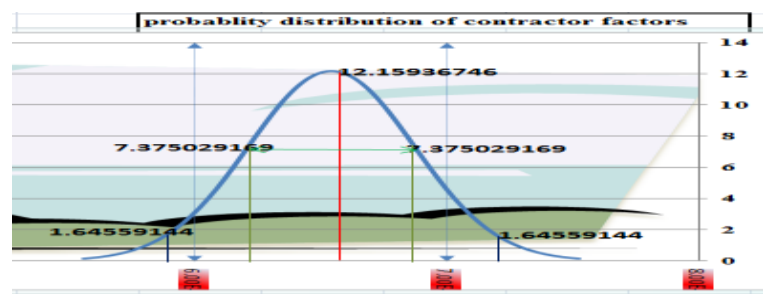

Fig 3 Probability Distribution of Contractor Factor (mean: 0.6543, standard deviation: 0.0328).(source; compiled by author)
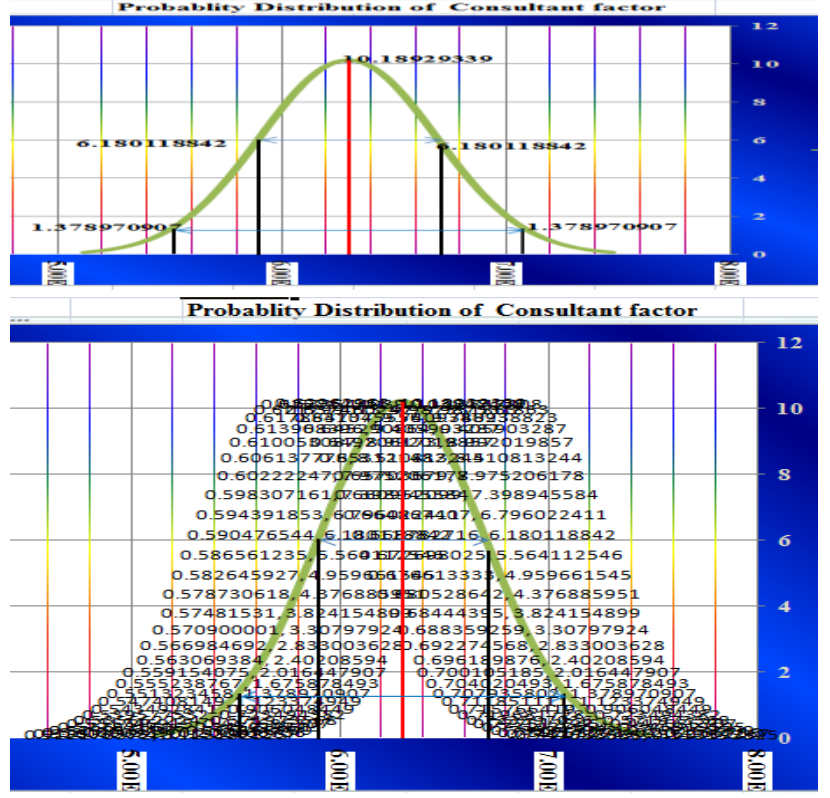

Fig 4 Probability Distribution of Consultant Factor (mean: 0.6296, standard deviation: 0.03915) (source;

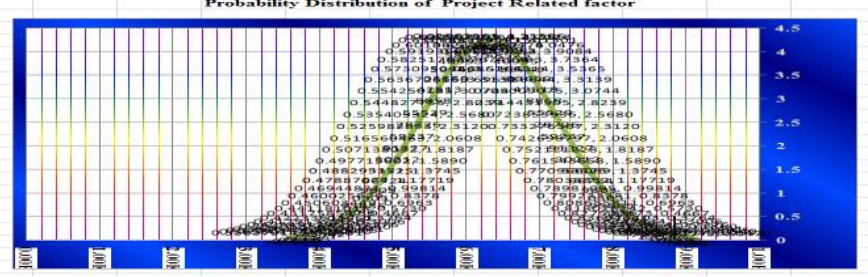

Retrieval Number: D9121118419/2019@BEIESP
Compiled by author)

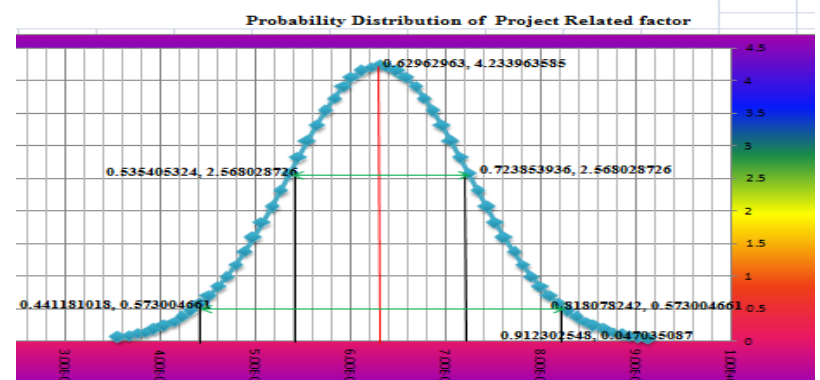

Fig 5 Probability Distribution of Project Related Factor (mean: 0.63, Standard deviation: 0.09422). (Source: compiled by author).

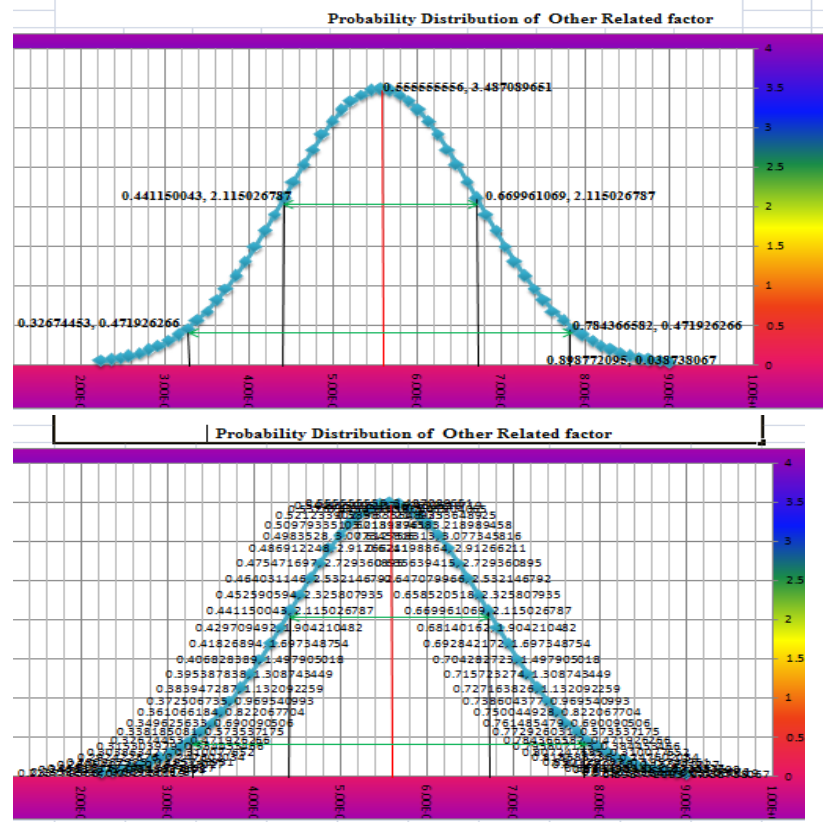

Fig 6 Probability Distribution of other Related Factor (mean: 0.555, Standard deviation: 0.1144). (Source: compiled by author)

The probability distribution of factors indicated that client and other related factors were the most influencing factor of cost overrun than others. In fig 2 and 6 , the score is less dense around the mean and the curve is flattest than others" this tells us the two factors are less significant than others. The distribution indicates a major cause of cost overrun were client factors and other related factors (such as price escalation, poor economic condition, corruption).

\section{Develop Simulation Model}

During the desk study, 19 construction projects were selected. The data was collected by reviewing project documents. Based on data gathered from the desk study, the entire project evaluated in desk study registered cost overrun. The project considered in desk study was 8 ongoing projects and 11 completed projects.Cost overrun for

Published By:

Blue Eyes Intelligence Engineering \& Sciences Publication

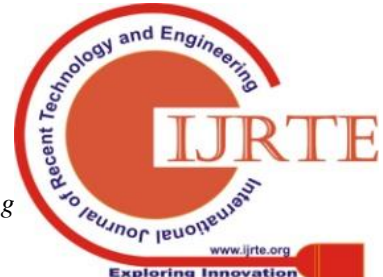


$100 \%$ complete $=$ actual cost - planned cost $=$ ACWP BCWP.

Cost overrun for ongoing project $=\mathrm{EV}-\mathrm{AC}$ where $\mathrm{EV}=$ $\%$ of completion *planned cost Percentage of cost overrun for $100 \%$ complete project

$=(($ actual cost - planned cost $) /$ planned cost $) * 100$
Percentage of cost overrun for ongoing project $=(($ earned value - actual cost)/planned cost $) * 100$

Table 2 desk study of 19 construction project ((Source: compiled by author)

\begin{tabular}{|c|c|c|c|c|c|c|}
\hline Project & $\begin{array}{c}\text { planned cost } \\
(\text { PV) }\end{array}$ & Actual cost (AC) & $\begin{array}{c}\% \text { of } \\
\text { Completion }\end{array}$ & $\begin{array}{c}\text { Earned } \\
\text { Value(EV) }\end{array}$ & $\begin{array}{c}\text { Cost variance } \\
\text { EV - AC }\end{array}$ & $\begin{array}{l}\% \text { of Cost } \\
\frac{\text { EV - AC }}{\text { PV }}\end{array}$ \\
\hline $\mathrm{P} 1$ & $686,511,964.39$ & $420,907,538.76$ & $60 \%$ & $411,907,178.60$ & $-9,000,360.16$ & $-1.31 \%$ \\
\hline $\mathrm{P} 2$ & $230,785,980.46$ & $301,215,857.82$ & $99 \%$ & $228,478,120.70$ & $-72,737,737.12$ & $-31.52 \%$ \\
\hline P3 & $420,085,436.60$ & $492,371,222.61$ & $78.09 \%$ & $328,044,717.40$ & $164,326,505.21$ & $-39.12 \%$ \\
\hline $\mathrm{P} 4$ & $48,000,000$ & $40,886,990.55$ & $68 \%$ & $32,640,000$ & $-8,246,990.55$ & $-17.18 \%$ \\
\hline P5 & $11,000,600$ & $14,000,000$ & $100 \%$ & $11,000,600$ & $-2,999,400.00$ & $-27.27 \%$ \\
\hline P6 & $13,000,000$ & $16,258,281.14$ & $100 \%$ & $13,000,000$ & $-3,258,281.14$ & $-25.06 \%$ \\
\hline $\mathrm{P} 7$ & $2,400,000$ & $3,400,000$ & $100 \%$ & $2,400,000$ & $-1,000,000.00$ & $-41.67 \%$ \\
\hline P8 & $2,800,000$ & $3,300,000$ & $100 \%$ & $2,800,000$ & $-500,000.00$ & $-17.86 \%$ \\
\hline P9 & $3,395,000$ & $4,100,000$ & $100 \%$ & $3,395,000$ & $-705,000.00$ & $-20.77 \%$ \\
\hline $\mathrm{P} 10$ & $6,768,393.00$ & $6,768,393.00$ & $25 \%$ & $1,692,098.25$ & $-5,076,294.75$ & $-75.00 \%$ \\
\hline P11 & $6,200,000$ & $6,197,645.08$ & $78 \%$ & $4,836,000$ & $-1,361,645.08$ & $-21.96 \%$ \\
\hline P12 & $1,883,359.68$ & $847,511.86$ & $35 \%$ & $659,175.88$ & $-188,335.98$ & $-10.00 \%$ \\
\hline $\mathrm{P} 13$ & $1,894,913.81$ & $1,821,123.38$ & $95 \%$ & $1,800,168.12$ & $-20,955.26$ & $-1.11 \%$ \\
\hline $\mathrm{P} 14$ & $75,612,137.98$ & $76,612,137.90$ & $100 \%$ & $75,612,137.98$ & $-999,999.92$ & $-1.32 \%$ \\
\hline $\mathrm{P} 15$ & $95,500,681.97$ & $101,031,539.20$ & $100 \%$ & $95,500,681.97$ & $-5,530,857.23$ & $-5.79 \%$ \\
\hline P16 & $75,384,384.99$ & $76,483,940.60$ & $100 \%$ & $75,384,384.99$ & $-1,099,555.61$ & $-1.46 \%$ \\
\hline P17 & $120,450,980.30$ & $121,302,420.60$ & $100 \%$ & $120,450,980.30$ & $-851,440.30$ & $-0.71 \%$ \\
\hline P18 & $155,384,940.90$ & $156,825,304.90$ & $100 \%$ & $155,384,940.90$ & $-1,440,364.00$ & $-0.93 \%$ \\
\hline P19 & $183,970,650.50$ & $184,344,450.90$ & $100 \%$ & $183,970,650.50$ & $-373,800.40$ & $-0.20 \%$ \\
\hline
\end{tabular}

Table 3 Percentage of cumulative frequency (Source: compiled by author)

\begin{tabular}{|l|r|r|r|}
\hline cost & frequency & \multicolumn{1}{|l|}{ cumulative } & percentage of cumulative frequency \\
\hline 0 up to 10 & 8 & 8 & $42.11 \%$ \\
\hline 10 up to 20 & 3 & 11 & $57.89 \%$ \\
\hline 20 up to 30 & 4 & 15 & $78.95 \%$ \\
\hline 30 up to 40 & 2 & 17 & $89.47 \%$ \\
\hline 40 up to 50 & 1 & 18 & $94.74 \%$ \\
\hline 70 up to 80 & 1 & 19 & $100.00 \%$ \\
\hline Grand Total & 19 & & \\
\hline
\end{tabular}

Simulation: Interval Probability

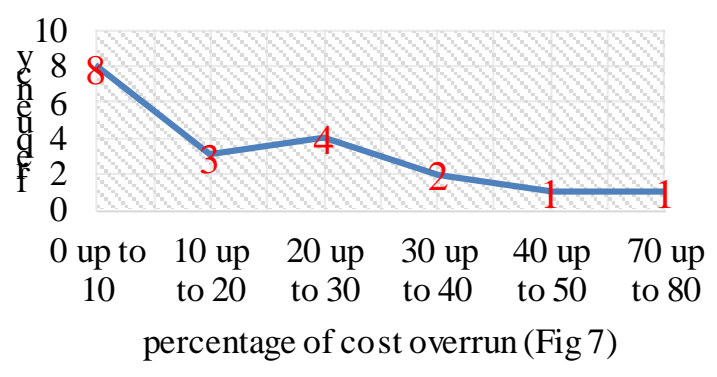

Figure 7 Interval probability model of the percentage of cost overrun and frequency. (Source: compiled by author)

Frequencies of cost overrun from 0 - $10 \%$ were 8 ; -those are Project 12, 13, 14, 15, 16, 17, 18 and 19.

Frequencies of cost overrun from $10-20 \%$ were 3 ; - those were projects 4,8 and 12 .

Frequencies of cost overrun from 20-30\%were 4: - those were Project 5, 6, 9 and 11.

Frequencies of cost overrun from $30-40 \%$ were 2: - those were Project 2 and 3

The frequency of cost overrun from $40-50 \%$ was 1: - that was Project 7

Frequencies of cost overrun from $70-80 \%$ were 1: - that was project 10 . 


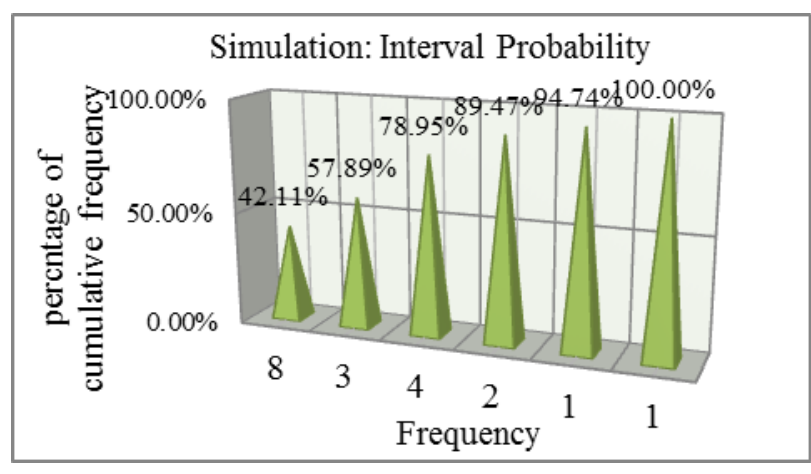

Figure 8 frequency VS percentage of cumulative frequency (Source: compiled by author)

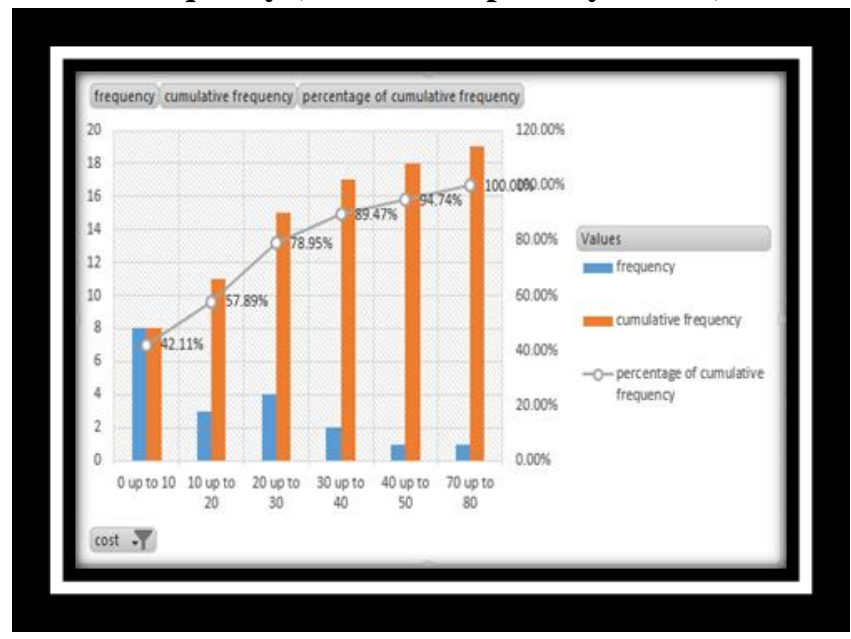

'Figure 9 Frequency, Cumulative frequency, and percentage of cumulative frequency model. (Source: compiled by author)

\section{CONCLUSION AND RECOMMENDATIONS}

\section{A. Conclusions}

According to the overall view of rank, fluctuation of construction material cost, inadequate project planning \& scheduling and poor economic condition (i.e. currency and inflation) were the $1^{\text {st }}, 2^{\text {nd }}$, and $3^{\text {rd }}$ level of influencing factor of cost overrun in a construction project with RII value of $0.7827,0.7777$ and 0.7432 respectively. This indicates the fluctuation of material cost was the main cause of cost overrun in most construction projects. e.g., rebar, RHS roof member and other import construction material were increasing their cost highly due to inflation and lack of currency in the current condition of the country. The normal probability distribution client factor, contractor factor, consultant factor, project-related factor, and other factor were distributed with a mean of $0.562962963,0.6543$, $0.62962963,0.62962963$ and 0.555555556 with a SD of $0.119481683,0.03280946,0.039153086,0.094224306$ and 0.114405513 respectively. Simulation model of cost overrun as shown on a model in fig 7 the large number frequency occurs 0 up to $10 \%$. This indicates the real cost of most construction projects increases by up to $10 \%$ over its budget and some projects exposed to cost overrun up to $80 \%$.

\section{B. Recommendations}

- Fluctuations in prices of raw materials and the cost of manufactured materials should be stabilized by breaking the monopoly of few suppliers and controlling the supply chain of the market.

- Appropriate funding levels should always be determined at the planning stage of the project so that regular payment should be paid to contractors for work done.

- $\quad$ Site managerial skills of contractors and subcontractors should be improved by conducting management courses and training to prevent cost overrun.

- To improve contractors' managerial skills, they shall need continuous personal development for personnel in the construction industry to update their knowledge and be familiar with project management techniques and processes, to have effective and efficient performances.

- The project manager should be sure the project spent time to define the project objective, scope, assumption, risk, budget, timeline and overall approach before starting the project.

- Project consultants should develop quality control and quality assurance plans to review and revise Contractor submittals such as material submittals.

\section{REFERENCES}

1. Aziz, R.F. (2013). Factors causing cost variation for constructing wastewater projects in Egypt. Alexandria Engineering Journal, 52(1), https://doi.org/10.1016/j.aej.2012.11.004

2. Brunes, F. \& Lind, H. (2014). Policies to avoid cost overruns: Critical evaluation and recommendations. Working Paper 2014:06, Section for Building and Real Estate Economics, Department of Real Estate and Construction Management, Centre for Banking and Finance (Cefin), School of Architecture and the Built Environment, Royal Institute of Technology, Sweden, 2014, pp. 1-16.

3. Gordon, S. (2010). Normal Distribution. University of Sydney, UPS.

4. Kaming Peter, O. P. (1997). Factors influencing construction time and cost overruns on high-rise projects in Indonesia. Journal of Construction Management and Economics, Volume 15, pp. No.1, pp. 83-94.

5. Memon, A.H. (2013). The way forward in sustainable construction Issues and challenges. International Journal of Advances in Applied Sciences, 2(1), pp. 1-8.

6. Morris, S. (1990). 'Cost and Time Overruns in Public Sector Projects', Economic and Political Weekly, Nov. 24, Vol. XXV, No. 47, pp. M154 $-168$

7. Nega, F. (2008). Causes and effects of cost overrun on public building construction projects in Ethiopia. Unpublished MSc thesis. Addis Ababa University: School of Graduate Studies, Ethiopia

8. Saidu, I. \&Shakantu, W.M.W. (2016). A study of the relationship between material waste and cost overrun in the construction industry. In: Windapo, A.O. (Ed.). The 9th Post graduate Conference:

9. "Emerging trends in construction organizational practices and project management knowledge area", 2-4 February, Cape Town, South Africa, pp. 124-134.

10. Shanmugapriya, S. \& Subramanian, K. (2013). Investigation of significant factors affecting time and cost overrun in Indian construction projects. $\begin{array}{lrr}\text { International } & \text { Journal of } \\ \text { Emerging Technology and }\end{array}$ 
Advanced Engineering, 3(10), pp. 734-740.

11. Stukhart\&George(1997) Estimating the Cost of Escalation\|, In The Engineer's Cost Hand110book Tools for Managing Project Costs, Edited by Richard E. Westney, P.E. Westney Consultants International, Inc. Houston, Texas, ISBN 0-8247-9796-5.

12. Subramani, T., Sruthi, P.S. \& Kavitha, M. (2014). Causes of cost overrun in construction. IOSR Journal of Engineering (IOSRJEN), 4(6), pp. 22788719. https://doi.org/10.9790/3021-0464010

13. Ubani, E.C., Okarche, K.A. \&Emeribe, S.C. (2011). Analysis of factors influencing time and cost overrun on construction projects in SouthEastern Nigeria. International Journal of Management Sciences and Business Research, 2(2), pp. 73-84.

\section{AUTHOR PROFILE}

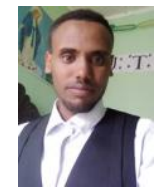

${ }^{1}$ Geletaw Taye, (MSc in Construction Engineering and management) Lecturer at Dilla University, Department of Construction technology and management, Dilla University ,Dilla , Ethiopia,

email:geletawtaye21@gmail.com, geletawtaye79@gmail.com
14. Windapo, A. O., \& Cattell, K. (2013). The South African construction industry: Perceptions of key challenges facing its performance development, and growth. Journal of Construction in Developing Countries, 18(2), 